\title{
BİR MUAMMA VE LUGAZ METNI HAKKINDA
}

\section{Bahadır GÜNEŞ*}

\section{$\ddot{O} z$}

Türkçenin yazı dili geleneği geçmişten bu güne gelişerek ilerlemiş, bu durum zengin bir külliyatın oluşmasını sağlamıştır. Bu külliyat içinde yazma eserler önemli birer unsur olarak kabul edilmektedir. Bu çalışmada muamma ve lugazlardan oluşan bir yazma eser içerik özellikleri itibarıyla tanıtılmaya çalışılmış, metinde geçen muamma ve lugazlarla ilgili örnekler gösterilmiştir. Ayrıca yazının sonuna metnin iç kapağı, ilk sayfası, silinmiş başlıkları gösteren örnek sayfa ve son sayfa eklenmiştir.

Anahtar Sözcükler: Yazma eser, metin, muamma, lugaz.

\section{ABOUT A MUAMMA AND LUGAZ TEXT}

\begin{abstract}
The language of the Turkish tradition of developing advanced past this day this situation has create rich corpus. The manuscripts are considered to be an important element in this corpus. In this study has been introduced as a manuscript content features of the muamma and lugaz and examples specified in the text. Also the inside cover of the text to the end of the text, the first page of the sample showing the deleted title page and the last page has been added.
\end{abstract}

Keywords: Manuscript, text, muamma, lugaz.

\section{Giriş}

Türk dili, ilk yazılı ürünlerinden bugüne kadar oluşturduğu kültürel birikimiyle geçmişten günümüze uzanan sağlam bir köprü meydana getirmiştir. Tarihî süreç içerisinde bu köprü üzerinde büyük bir külliyat meydana getirilmiştir. Türkçenin bugünü üzerinde yapılan çalışmaların yanında geçmişte yazılan, el yazması ve nadir eser ${ }^{1}$ özelliği taşıyan metinler de araştırmacılar tarafından inceleme konusu yapılmaktadır. Türkiye ve Türkiye dışındaki kütüphanelerde telif ve tercüme olmak üzere bu şekilde birçok eser bulunmaktadır. Bu durum, dil ve edebiyatın geçmişe ait zengin birikimini göstermesinin yanında konuya ilgi duyan her araştırmacının ilgisini cezbeden bir unsur olma özelliği de taşımaktadır.

$\mathrm{Bu}$ çalışma, bir muamma ve lugaz metnini ana hatlarıyla tanıtmayı amaçlamaktadır². Söz konusu metin, Süleymaniye Kütüphanesi B. Vehbi bölümünde olup metnin eski kayıt numarası 1542; yeni kayıt numarası 1489 'dur. Metnin içeriğinde eserin müellifi, telif tarihi,

\footnotetext{
* Yrd. Doç. Dr.; Karadeniz Teknik Üni. Edebiyat Fakültesi, Türk Dili ve Edebiyatı Bölümü, bahadir.gunes@hotmail.com.

${ }^{1}$ El yazması ve nadir eserlerle ilgili geniş bilgi için $b k$. (Abdulkadiroğlu, 1988: 1-48).

${ }^{2}$ Muamma ve lugaz metinleriyle ilgili yapılmış çalışmalar için bk. (Çapan, 2005: 205-222; Hamza, 2011; Ayar, 2011).
} 
müstensihi ve istinsah tarihi hakkında herhangi bir bilgi bulunmamaktadır. Eserin zahriyye ${ }^{3}$ bölümünde "Muhammed Paşazade İbrahim" adına rastlanmaktadır. Bu kişi, eserin sahibi, bir başka deyişle eseri kütüphanesinde bulunduran şahıstır.

Eser, cd ortamında ve pdf formatında elde edildiği için metnin cildi, kâğıdının özellikleri ve ebatları hakkında herhangi bir veriye ulaşılamamıştır. Eser, iki adet kapak sayfasının dışında 44 varaktan oluşmaktadır. Nesih yazı türü kullanılan metin harekesizdir. Metnin varak numaraları -muhtemelen sonradan- bugünkü rakamlarla gösterilmiştir. Eserdeki satır sayısı her sayfada değişiklik göstermektedir. Bunun yanında muammaların bulunduğu ilk 8 varakta başlıkların yazılı olduğu satırlarla birlikte ortalama 17-18 satır bulunmaktadır. Sonraki bölümlerde ise satır sayısı değişiklik göstermektedir. Buna göre 9. varakta 10; 9. varaktan 35 . varağa kadar takip eden her bir varakta başlıklarla birlikte toplam 17 satır bulunmaktadır. 35-b; 38-b; 42-b; 43-a; 43-b'de 16 satır mevcuttur. Son varak olan 44-a'da ise 4 satır vardır ${ }^{4}$.

\section{Bilmece / Muamma / Lugaz}

Bilmece, lugaz, muamma genellikle aynı veya benzer türler kabul edilerek ele alınmıştır. Ancak Türk edebiyatı içinde divan ve halk edebiyatı sahalarında ilgili terimler birbirinden ayrı tutulmuştur. Buna göre, "bilmeceler, tabiat unsurları ile bu unsurlara bağlı hadiseleri; insan, hayvan ve bitki gibi canlıları; eşyayı, akıl, zekâ ve güzellik nev'inden mücerred kavramlarla dinî konu ve motifleri $v b$. kapalı bir şekilde yakın-uzak münasebetler ve çağrışımlarla düşünce, muhakeme ve dikkatimize aksettirerek bulmayı hedef tutan kalıplaşmış sözler" (Elçin, 1993: 607'den aktaran Aça vd. 2011: 559) biçiminde tanımlanmıştır.

Muamma, âşı edebiyatı geleneğinde âşıkların sorduğu, bütünüyle manzum bilmeceleri karşılayan bir terim olarak kabul edilirken lugaz ise daha çok divan şairlerinin yazdıkları manzum bilmece metinlerini adlandırmak için kullanılmıştır. Ancak bu türleri bütünüyle divan veya âşık edebiyatına mal etmek mümkün değildir (Aça vd. 2011: 559).

Sözlük anlamı gizlenen ve karışık gösterilen şey anlamına gelen muamma, remiz ve ima yoluyla yani doğrudan değil, dolaylı olarak, işaret ile bir isme delalet eden sözdür. Şairin bir ismi şiirinde gizlemesi ta'miye; bu gizlenen isim muamma olarak adlandırılır'.

\footnotetext{
${ }^{3}$ Zahriyye, yazma eserlerde kitabın cilt kapağının iç tarafı olup buralarda temellük kayıt ve mühürlere, tayin, azil, doğum, evlenme gibi ailevi ve mesleki gizli kayıtlara rastlamak mümkündür (Abdulkadiroğlu, 1988: 10).

${ }^{4}$ Bazı sayfalarda muamma ve lugazla ilgili ipucu niteliği taşıyan harflere yer verilen ve başlık satırı sayılabilecek yazılar silinmiştir. İlgili sayfalardaki satır sayıları belirtilirken bu bölümler de dâhil edilmiştir.

5 "Bir katre mâ düşünce gülün kalb-i pâkine / Nâmım yazıldı her varak-ı tâb-nâkine" (Namık Kemal). Gül (g-l) kelimesinin kalbi, ortası demektir. Ortasına mâ (m, elif) düşmesi ile "Kemal" ismi ortaya çıkar. (Saraç, 2007: 289, 294). 
Lugaz, insan isminin dışında bir şeyin özelliklerinin söylendiği ve dinleyiciden bunun ne olduğunun sorulduğu, genellikle aruzun fâilâtün fâilâtün fâilün kalıbıyla yazılan şiir, bir tür manzum bilmece veya hünerdir. Lugazı bilmecelerden ayıran en önemli özellik, lugazın yazarının imzasını taşımasıdır. (Saraç, 2007: 292; Olgun, 1936: 72; Elçin, 2014: 619-620; Pala, 2005: 291).

Muamma, şiirsel bir oyun veya bir tür bilmecedir. Dolayısıyla muamma yazmak şairlik işinden çok, bir zekâ ve yetenek işidir. Muammaya benzer bir tür de lugazdır. Ancak lugazda herhangi bir şey konu edilirken muamma yalnız insan adları için yazılır (Bilkan, 2000: 12). Ayrıca lugazın muammadan ayrılan özelliklerinden biri de çözüme yarayacak açıklamayı kendisinde bulundurmasıdır (Elçin, 2014: 620).

Çalışmaya konu olan eserin ilk 8 varağında şahıs isimleri söz konusu edildiğinden bu bölümü тиатта; 9. varaktan eserin sona erdiği 44. varağa kadar olan bölümde ise soyut ve somut olmak üzere çeşitli kavramlar ele alındığından bu bölümdekileri de lugaz olarak adlandırmak doğru olacaktır. Ayrıca metnin 42. varağında; yani lugazların olduğu bölümde 17. yüzyıl şairi Nabi, bir beytinden hareketle muammaya konu edilmiştir.

Buna göre ilgili metinde, sorulan isimlerin bir bölümü tamamen silinmiş olmakla birlikte toplam 84 tane muamma bulunmaktadır. $\mathrm{Bu}$ muammalara konu olan isimlerin bir bölümü birkaç defa ve farklı biçimlerde tarif edilmiştir.

9. varaktan itibaren sunulan lugazlarda ise genellikle kullanılmakla birlikte, tamamı "nedür ol ... / ol nedür / ol ne şeydür" gibi kalıp ifadelerle başlamamaktadır.

Muamma ve lugazın yukarıda verilen tanımlamalarına aykırı olarak metinde sorulan kavram ve başlangıç ifadesi lugazı andırsa da söz konusu lugazın sonunda "bu muammma..." şeklinde ifadeler yer almaktadır. 18. varakta yer alan "mum şamdan" lugazı bu durumu örnekler.

\subsection{Muammalarda Geçen Adlar}

Çalışma konusu olan metnin ilk sekiz varağının tamamında ve 42. varağında bir tane olmak üzere toplam muamma sayısı 84'tür. Ancak bazı isimler birkaç defa ve farklı tariflerle muammalarda yer almıştır. Ayrıca 2-a'da 1; 2-b'de 2; 3-b'de 1; 4-b'de 1; 5-b'de 1 olmak üzere muammalarda geçen isimler silinmiş ve söz konusu muammalar Farsça yazılmıştır. Ayrıca 9a'da yer alan ve "Yusuf" adının konu edildiği muamma da Farsçadır.

Metinde birkaç defa görülen adlardan Hüseyin 6; Ahmed 5; Osman 5; Ali 4; Ömer 3; İbrahim 3; Yusuf 3; Kemal 2; Kasım 2; Mustafa 2; Bektaş 2 defa muammaya konu olmuştur. 
Geriye kalan muammalardan ad bölümleri tamamen veya büyük oranda okunamayan, “...” ile gösterilen 25 muammanın dışında kalan Hızır, Menar, Said, Hasan, Celal, İlyas, Süleyman, Ziya, Mahmud, Sinan, Rahmi, Halil, Receb, Mehmed ve Nabi adları da birer kez muammalarda yer bulmuştur.

Metinde geçen muammalardan bazıları aşağıda gösterilmiştir:

\section{Be-nām-ı Ahmed}

Koparur başına bir gün kıyāmet

Meded āhir o māh-l serv-kāmet

\section{Be-nām-ı Osmān}

Gözüm gitmez çü zülfüñden dem-ā-dem

Nice bakmayısar bes aña ādem

\section{Be-nām-ı $\dddot{O} m e r$}

ḩāl-i ruhsāruña naẓar itdim

merdüm-i dide oldugin bildim

\section{$B e-n \bar{a} m-\iota s a^{\prime} \bar{i}$}

kes müderris ayag்ını hem mu 'iddüñ başını

ko ayà̈ı baş yerine tām eylesin nāmını

\section{Be-ism-i Celāl}

üç otuzla bir otuz bir ad olur

bu тu'ammāyı bilen üstād olur

\subsection{Lugazlarda Geçen Kavramlar}

Metinde lugaza konu olan ve tarifi yapılan kavramlar1, somut ve soyut kavramlar biçiminde ikiye ayırmak mümkündür. Metinde silik ve okunup anlamlandırılmasında güçlük çekilen kavramlar ise diğerleri başlığı altında değerlendirilmiştir. Metindeki bazı lugazlarda birbiriyle ilgili birden fazla kavram bir arada tarif edilmiştir. Çalışmada bu özellikteki lugazlar birlikte gösterilmiştir. Ayrıca ilgili bölümlerde kavramlar belirtildikten sonra her başlık için birer örnek verilmişsir.

Metinde yer alan lugazlar için yapılan açıklamaların uzunluk ve kısalığı farklılık göstermektedir. Bazı lugazlar iki mısra hâlinde; bazıları dört mısra; bir bölümü ise on ve daha fazla mısra ile tarif edilmiştir. Bazı lugazlarda birden fazla kavram tarif edildiği için açıklamalar 
uzun olabilmektedir. Ancak metinde bu durumun genel bir kuralı yoktur. Zira tek kavram da zaman zaman uzun bir şekilde anlatılabilmektedir.

\subsubsection{Somut Kavramlar}

Muamma ve lugaz metninde tarifi yapılan ve somut olarak kabul edilebilecek kavramlar niteliklerine göre eşyalar, yiyecek içecekler, mekân ve mekâna ait unsurlar, uzuv / organ, taşııt ve hayvanlar şeklinde alt başlıklara ayrılarak ele alınmıştır.

\subsubsection{Eşyalar}

Eşyalar, evle ve meslek gruplarıyla ilgili olmak üzere iki alt başlık altında ve her alt başlık kendi içinde çeşitli kollara ayrılarak gösterilmiştir ${ }^{6}$. Buna göre eşyalar, evle ilgili olanlar (evin içinde ve dışında kullanılanlar) ve meslek gruplarıyla ilgili olanlar (kırtasiyecilik, terzilik, askerlik, ticaret, müzik, tarım ve çilingirlik) şeklindedir.

\subsection{Evle İlgili Eşyalar}

Evle ilgili eşyaları, evin içinde ve dışında kullanılanlar olmak üzere iki başlıkta göstermek mümkündür.

\subsection{Evin İçinde Kullanılanlar}

Evin içinde kullanılan eşyalar; kişisel eşyalar, dekor amaçlı kullanılanlar, mutfakta kullanılanlar olmak üzere üç başlıkta gösterilmiştir.

\section{Kişisel Eşyalar}

Doğrudan insanın kullandığı, kişisel eşya sayılabilecek unsurlar arasında tırnak bıçağı, gözlük, çakmak, mum makası mum kibriti, sancak, na’leyn (ayakkabı), ilik düğme sayılabilir. Bunlardan 10-b'de yer alan tırnak bıçă̆ının tarifi şöyledir:

$$
\begin{aligned}
& \text { nedür ol şahș-ı ẓarîf şekl-i nah îf } \\
& \text { kendü kuvvetlü lik cismi ża ‘̈f } \\
& \text { sinesi sırr-ı sırr-ı efkār } \\
& \text { yoḳdur zaḥm ile degül bīmār } \\
& \text { gāh bir bedre māh itse kıı̄̄n } \\
& \text { ayırur anı hilālinden ol ān }
\end{aligned}
$$

\footnotetext{
${ }^{6}$ Açıklaması yapılan kavramlardan tamamen silik veya okunamayacak durumda olanlar "diğerleri” başlı̆ğ altında gösterilmiştir. Ancak birkaç kavramın bir arada açıklandığı lugazlarda kavramlardan biri veya ikisi okunamayacak durumda olup diğerleri okunabilmişse bunlar ilgili oldukları başlıklara dâhil edilmiş, okunamayan kısımlar “..." ile gösterilmiştir.
} 
șavm-ı dāvudı kendüye 'ādet ider

far $\dot{z}-1$ kurrasina ri '`āyet ider

șlfat-ı cismi șuretā hindi

merkezinde timur kazuk kendi

\section{Dekor veya Görüntü Amaçlı Kullanılanlar}

Ev içinde ve daha çok dekor olarak kullanılan unsurlar arasında mum şamdan fanus, çalar sa'at, frengî mûm, gül-âb-dân başl1klarıyla verilen unsurlar sayılabilir. Bunlardan 23-a'da yer alan gül-âb-dân'ın tarifi şu şekildedir:

nedür ol kim tebesinde gözi var

kime hem-dem olursa hạlin à்lar

\section{Mutfakta Kullanilanlar}

Mutfakta veya yemek pişirmek için kullanılan unsurlar arasında sacayak ve tennûr (tandır) gösterilebilir. Bunlardan 24-a'da bulunan sacayak aşağıdaki gibi sorulmuştur:

ol nedür kim gözi bir ayaġı üç

anı bilmek kolaydur bilmemek güç

\subsection{Evin Dışında Kullanılanlar}

Evle ilgili; ancak daha çok evin dışında kullanılan unsurlara dair metinde fener, nerdübân (merdiven), çıkrık tespit edilmiştir. 24-a/b'de yer alan nerdübân şöyle tarif edilmiştir:

nedür ol kim iki bāldür țayakdur

teni başdan başa cümle ayaḳdur

anı götürince ol yürimez

kamu aña binerler ol yayakdur

\subsection{Meslek Gruplarıyla İlgili Eşyalar}

$\mathrm{Bu}$ başlık altında toplam yedi meslek grubuna ait unsur tespit edilmiştir. Bunlar kırtasiyecilik, postacılık, terzilik, askerlik, tüccarlık, tarım, çilingirlik ve müzisyenliktir. 


\section{Kırtasiyecilikle İlgili Olanlar}

Bazıları birkaç defa lugaza konu olan, yazı veya kırtasiye malzemesi olan kavramlar tuğra, divît kalem kâğıd, sîm divit, şeklinde belirtilmiştir. Bunlardan 24-b'de geçen kalemin tarifi şu şekildedir:

Ol nedür kim heybeti anuñ derāz

Herkese itmekde dā'im keşf ü rā̃z

Her kim isterse anı a'māl ider

İki dendānın kırup pā-māl ider

Cāmesi gül-gūn olur gāh $\bar{i}$

Á̀glasa derdin olur başı siyāh

Meskeni gāhī ves $\bar{i}^{\prime} g \bar{a} h$ ṭar

Kāmil olan anı gāh elde țutar

\section{Postacllıkla İlgili Olanlar}

Postacılıkla ilgili olan unsurlardan mektûb (2) tespit edilebilmiştir. Söz konusu kavramın 37-a'da bulunan tarifi aşağıda gösterilmiştir:

nedür ol kim anuñ yokdur lisānı

velī her dilçe eyler ol beyānı

ayag் l yok yine eyler teferrüc

kimi rūmī kimi hindūstān $\bar{i}$

\section{Terzilikle İlgili Olanlar}

Metinde terzilikle ilgili mikrâs (makas), öreke, keten, gergef, mekik tespit edilmiştir. Bunlardan 23-a'da yer alan mikrâsin tarifi şu şekildedir:

birer gözlü nedür ol iki üstād

her işde birbirine eyler imdād

birisi yalñzz ḳalsa muhașṣal

olur kārından ol dahi mu'atțal

\footnotetext{
${ }^{7}$ Aslında keşfi-râz (bir sırrı ögrrenme) şeklinde olması gereken tamlama, metinde keşf ü râz biçiminde yazılmıştır. 
șanasin cism-i vāhiddür ki bunlar

$\dot{g} \imath d \bar{a} y$ bir ag̀zıdan ekl iderler

\section{Askerlikle İlgili Olanlar}

Askerlikle ilgili sayılabilecek eşyalar arasında tüfenk (2), mızrak, yay tespit edilmiştir. Söz konusu unsurlardan tüfenk'in 33-a'daki sunuluşu aşağıda gösterilmiştir:

bil nedür ol çatlayası kııcağız

kaldı ḳondukda ḳaba ḳo çatlasun

borusı țutmış başında o dīnār

bir țabanca ur togrusin patlasun

\section{Tüccarlıkla İlgili Olanlar}

Bir yönüyle ticarette de kullanılan ağırlık ölçme aracı terâẑิu (2), metinde tespit edilen tek örnektir. Söz konusu örnek iki ayrı yerde, farklı biçimlerde anlatılmıştır. Bunlardan 35a'daki tarif Farsçadır. 31-a'daki sunuluş ise şöyledir:

$$
\begin{aligned}
& \text { nedür ol kim iki dil-ber karındaş } \\
& \text { ki itmezler biribiriyle pür-ḩāş } \\
& \text { üçer ayag் vardur göge tọgrl } \\
& \text { mücevvefdür ikisinüñ de bag่rl } \\
& \text { berāberdür ikisinüñ g̀ddāsl } \\
& \text { biribirine vardur iktitāsı } \\
& \text { kaçan biri ġ̀āya țāmi olur } \\
& \text { öbür kardaşı kalkar māni `olur } \\
& \text { ne virseñ yirler anı bì-tekellüf } \\
& \text { çeker bunı arayan çok te'essüf } \\
& \text { cevāb isterler ise bu su'àle } \\
& \text { ur ey vaṣli terāzūu-yı hayāle }
\end{aligned}
$$

\section{Tarımla İlgili Olanlar}

Tarımla ilgili unsurlardan tespit edilen tek örnek oraktır. 26-a'da bulunan ilgili aletin tarifi aşağıda gösterildiği gibidir: 
nedür ol burnı egri şahṣ-ı nā-dān

ot otlar gāhçe mānend-i hayvān

\section{Çilingirlikle İlgili Olanlar}

Çilingirliği ilgilendiren kavramlardan yalnız kilid tespit edilebilmiştir. 40-a'daki tarif şu şekildedir:

ol ne şeydür biri ünșā biri er

ișmetiyle oldılar meşhūrlar

ki tecemmu'itse er ol duhteri

nā-gehān eyler tevellüd birbiri

\section{Müzisyenlikle İlgili Olanlar}

Müzikle ilgili tespit edilen tek unsur nây (ney)'dir. Metinde 17-b'de bulunan tarif şöyledir:

ol nedür kim aġzı vardur dili yok

işāretle söyleşür bilgisi çok

hem riyāżet ehlidür perhī tuțar

zevāde almaz mizācr yil yuțar

göz kapar 'uşşāḳına delìr gibi

kevnini parmakladur kaşmer gibi

bekrilerle bekrïdür derviş ile derviş

başına şapka giyer şekli keşiş

niçe yüz biñ kerre biñ başındadur

hesāb-ı ebcedle altmışındadur

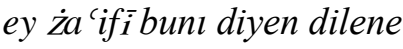

șad hezārān äferīnler bilene

\subsubsection{Yiyecek İçecekler}

Yiyecek içecek genel başlığı altında yer alan unsurlar yemek, meyve, sebze, kuru yemiş, içecek başlıklarından ibarettir. 


\section{Yemek}

Metinde lugaz içinde geçen yemek türü pilav'dır. Söz konusu yemek, 21-b ve 22-a'da yer almaktadır:

nedür ol kubbe-i simin ü billūr

iner gāh içe aniñ üstüne nūr

eli àgaçlı bir niçe fedāyi

kaza ḳaza yıkarlar ol bināyı

\section{Meyve}

Metinde meyve adı olarak sunulan kavramlar incir, karpuz (2), karadut ve kavun'dur. Bunlardan karpuz'un 44-a'daki tarifi şu şekilde yapılmıştır:

kudret-i yezdāndur anuñ ḩānesi

og்lunuñ karnında yatur anası

og்lunı öldür anasın göm yire

biñ dāne olurmış bir dānesi

\section{Kuru Yemiş}

Yiyecek kategorisi içinde kuru yemiş olarak sunulanlar fistık ve kestanedir. Bunlardan fistık 21-b'de; kestane ise 26-a'da yer almaktadır. Fıstığın metindeki tarifi şöyledir:

nedür ol kim yapusı hāane hāne

içinde tuhfesi var dāne dāne

açılmaz kapusı berkdür yapusı

meger yıl yıl açıla yana yana

\section{İçecek}

Metninde tespit edilebilen tek içecek adı kahvedir. 22-a'da tarif edilmiştir:

nedür ol seyyāhn-l 'ālemdür gezer

... gūyā var sine bağrını ezer

ehl-i diller șordılar hālü̈ñ nedür

gezdügin yerlerde aḥvālün nedür

çünki ṣorduñ size hạlim diyeyim 
keyfim ile size hașlet vireyim

bir zamān tahtım idi hind u yemān

şimdi faǵfūr iline düşürdi zamān

\subsubsection{Mekân ve Mekâna Ait Unsurlar}

İncelenen metinde mekâna dair tespit edilenler; minâre câmi', hammâm (2), yel değirmeni, çadır şeklindedir. Bunlardan hammâmın 22-b'deki sunuluşu şöyledir:

ol ne şeyh halveti kim gözi yaşlu dā 'imā

günbed-i tācln görenler dir aña ehl-i riyā

meclisine kim irişse $\dot{g} \imath l l$ ü ğış̧lın pāk olur

terk ider tāc u kabāyl ger emīi ü ger gedā

\subsubsection{Uzuv / Organ}

Anılan metinde uzuv veya organ adı olarak tarif edilen tek kavram memedir. 24-a'da yer alan söz konusu uzuv, aşağıdaki gibi açıklanmıştır:

ol ne ḥav̇̇ol ki anuñ simdendür ...

$\bar{a} b-\imath$ șâf-ile leb-ā-leb țolmış anuñ dāhili

șalınur da bir ḥakim ḩāz tek ic̄āddur

çifte havż itmiş tașannu' iki çeşme ḳabili

ābını vakf eyleyüp bir perīnāzır eylemiş

kandura ol āb-ile ‘ālemde çok ehl-i dili

\subsubsection{Taşıt}

Metinde taşıt kategorisi içinde yer verilen kavramlardan yalnız sefine (gemi, vapur) tespit edilebilmiştir. 35-b'de yer alan söz konusu kavramın tarifi şu şekilde yapılmıştır:

bir ulu șaḥrāda gördüm nā-gehān

bir niçe kuşlar uçarlar her zamān

her birinüñ tagia beñzer lengeri

kendü ḳara akdurur ḳanatları

h̆ışmile bunlar bulut gibi uçar

gözlerinden gāhīodlar șaçar 


\subsubsection{Hayvan}

Lugazlarda geçen hayvanlar çekirge ve sümüklü böcektir. Söz konusu hayvanlardan sümüklü böceğin 25-b'deki tarifi şu şekildedir:

evin arḳasına urmış bir ādem

çıkar șahrāyl seyr ider dem-ā-dem

eli yok ayagi yok boynuzı var

velī kande giderse hem izi var

\subsubsection{Soyut Kavramlar}

Metinde lugazlarda tarifi yapilan unsurlardan ikinci grup, soyut kavramlardan oluşmaktadır. Bu bölümde yer verilen unsurlar; sayı, canlılara özgü nitelik ve durumlar, zaman dilimi, astronomi, ad, gölge, dinî kavramlar, renk ve alfabe şeklinde başlıklara ayrılmıştır.

\subsubsection{Sayı}

Anılan metinde lugaza konu olan tek sayı ikidir. 14-b ve 15-a'daki tarife göre $i k i$ sayıs1 şu şekilde sunulmuştur:

ol ne dörtdür altı ile ikidür

lafžile ma'nāda da dahi ikidür

birinüñ nıșfi ikidür şübhesiz

ol birinüñ dahi șeliși ikidür

ikisinüñ hamsi de iki olur

ikisi bir yere gelse ikidür

\subsubsection{Canlılara Özgü Nitelikler / Canlıların Maruz Kaldığı Durumlar}

Canlılara özgü olan veya canlılar tarafindan yaşanan durumlara dair ilgili metinde altı kavram tespit edilmiştir; gazab, uyku, deri, sakal ve tıraş ve meyyit (ölü). Bu kavramlardan 43a'da yer alan meyyit (ölü), şu şekilde tarif edilmiştir:

ol nedür kim yüzdür anuñ parmag்l

sekiz ayak üzre țurur țurmagi

beș başı var beş dili var dört cānı

yek ‘̄arif gerek kim bile anı 


\subsubsection{Zaman Dilimi}

Zaman dilimini belirten kavramlar klş yaz ve gece gündüzdür. Buna göre metinde 23b'de geçen gece gündüzün tarifi aşağıdaki gibidir:

nedür ol biri leylā biri mecnūn

ikisinüñ dahi hạli dīger-gūn

biri birine olmış 'āşılk u zār

veli hasretde kalmışlar giriftār

\subsubsection{Astronomi}

Astronomi ile ilgili olarak lugazda geçen kavramlar, pervîn ile güneştir. Bunlardan 39-a / b`de yer alan güneşin metindeki tarifi şu şekildedir:

ol nedür ki bir münevver topdur

gayet ile pek güzel kaçupdur

șubḥ u mesā cihānı ider güzzer

böyle iken hāke yüzini sürer

kātibā her kim bilürse sırrını

gün gibi olsun yüzi nūr-ı kamer

\subsubsection{Ad}

Ad kategorisinde yer alan ve lugaz olarak sorulan kavram isimdir. Metnin 35-a sayfasında yer alan tarife göre ismin sunuluşu şöyledir:

o nedür ki bir hakikat hem nāz

ülfet itdügi yerden ayrlmaz

\subsubsection{Gölge}

Soyut kavramlar kategorisinde yer verilen unsurlardan biri de gölgedir. Metnin 32-b ve 33-a bölümünde bulunan söz konusu kavramın tarifi şu şekildedir:

ben bugün șahrada gördüm bir ḩarïf

senden ayrılmam didi ahşāma dek

kande gitsem bildürür 'azmüm benüm

sen eger istesen teferrüc-i şāma dek 


\subsubsection{Dinî Kavramlar}

Metinde din ile ilgili kavramlardan kader, çihâr-l yâr-i güzîn ve namâz tespit edilmiştir. Metinde 38-a / b'de geçen çihar-ı yar-i güzinin tarifi aşağıda gösterilmiştir:

bir elif üç 'ayın ile gördüm bile

bir elif ü̧ 'ayın ile gelmez dile

bir elif üç 'ayın ile gelse dile

müstakìm 'ārif gerek anı bile

\subsubsection{Renk}

Metinde renk olarak lugazın konusu olan tek renk, 27-b / 28-a'da bulunan karadır. Söz konusu kavramın açıklaması şu şekilde yapılmıştır:

ol nedür kim fikr-i dā' im kinedür

halk-l 'ālemde işi 'aksinedür

müdbir ü müfsid ü olur yıkııı

sürme-i mekrile gözden kayıcı

og்lu tọ̇ar anasında toğıçak

yire girsün buncılayın yoruçak

\subsubsection{Alfabe}

İncelenen metinin 42-a / b bölümünde $a b c$ başlığıyla alfabe de lugazlar içinde yer almıştır. Abcnin metindeki anlatımı aşağıda gösterilmiştir:

ol ne sözdür ki ne hadīs ola ne ḳurān

anı ne perī söylemiş ola ne insān

tevrāt u zebūr u incī dahi degildür

‘āciz bunı fehm itmede ... ile saḥbān

bir sözdür o kurān ḥadīsiñ arasında

cibrî̀ kelāmı dimiş ol söze niçe cān

... sūresinü̃n ḥarfi olupdur o ... çār

mānend-i 'anāṣlr görinür her biri yeksān 


\begin{abstract}
bir harfi cüdā olsa eger kim rakamından
yerinde anun çār görür zümre-i 'ārifāan

iki dahi başın alup gitse gitse aradan

șanmañ o kelāmuñ irişe dördüne nokṣān

üçler gibi üç harfi dahi g̀āyet olursa

yerinde anuñ dördi olur yine kemā-kān

encüm ile dördi dahi eylese ġybet

maḥsūbı vü mektūbı anuñ çār olur erkān

her kim ki murādìye haber virse bu sözden

tilmīz ola niçe zamān thfl-ı dil ü cān
\end{abstract}

\title{
1.2.3. Diğerleri
}

Metinde somut ve soyut kavramların dışında kalan ve başlık bölümleri büyük oranda veya tamamen silinmiş oldukları için tam manasıyla aydınlatılamayan lugazların sayısı 51 'dir. Söz konusu lugazların başlık kısmının dışında kalan açıklamalar büyük oranda okunabilmektedir. Buna göre örnek olmak üzere 21-b'de yer alan ve başlığı silinmiş olmakla birlikte, açıklamaları yazılı olan bir lugaz aşağıda gösterilmiştir:
nedür ol kal 'a-i pākiże gevher
pusuya girmiş anda niçe erler
ḳızllı ḳaralı șarılı aḳlı
țururlar anda hāàżr şöyle șaḳlı
ki her kim feth iderse ol hișārl
bulur ol demde ol erler mezarl

\section{Sonuç}

$\mathrm{Bu}$ çalışmada, hakkında sınırlı bilgi bulunan bir muamma ve lugaz metni, içerdiği unsurlar bakımından tanıtılmaya çalışıldı. Metnin ilk sekiz varağı ve 9. varağın bir bölümü muammalardan oluşmaktadır. $\mathrm{Bu}$ bölümde toplam 84 adet muamma tespit edilmiştir. Muammalarda geçen adlar farklılık göstermekle birlikte, bazıları 5-6 defa geçmektedir. Bunun yanında bazı muammaların başlık kısmı silinmiş ve açıklama kısımları Farsça yazılmıştır. 
Metnin 9. varağından itibaren lugazlar başlamaktadır. Bu bölümde genel itibarıyla somut, soyut ve diğerleri olmak üzere açıklamaları farklı olan toplam 125 ayrı lugaz bulunmaktadır. Lugazlardaki kavramlardan bazıları birkaç defa, farklı şekillerde tarif edilmiştir. Somut kavramlar kendi içinde alet ve araç gereçler, yiyecek içecekler, mekân ve mekâna ait unsurlar, uzuv / organ, hayvanlar, taşıt şeklinde ayrılmaktadır. Soyut kavramlar ise sayı, canlılara özgü nitelik ve durumlar, zaman dilimi, astronomi, ad, gölge, dinî kavramlar, renk ve alfabe gibi başlıklar hâlinde değerlendirilmiştir. Diğerleri adı altında yer verilen lugazlar ise başlıkları tamamen veya büyük oranda silinmiş; ancak açıklama kısımları okunabilenlerdir.

\section{Kaynaklar}

ABDULKADİROĞLU, A. (1988). Edebiyatta Metodoloji Açısından Elyazmaları ve Nadir Eserler Üzerine Notlar-I. GÜ Gazi Eğitim Fakültesi Dergisi, 3, 1-48.

AÇA, M.; GÖKALP, H ve KOCAKAPLAN, İ. (2011). Başlangıçtan Günümüze Türk Edebiyatında Tür ve Şekil Bilgisi. İstanbul: Kesit Yayınları.

AYAR, N. (2011). Millet Kütüphanesi Ali Emiri Manzum 567'deki Lugaz Mecmuası (vr. 245280 Metin-Inceleme). Yayımlanmamış Yüksek Lisans Tezi, İstanbul: Marmara Üniversitesi Türkiyat Araştırmaları Enstitüsü.

BİLKAN, A. F. (2000). Türk Edebiyatında Muamma. Ankara: Akçağ Yayınları.

ÇAPAN, P. (2005). 18. Yüzyıl Tezkirelerinde Örneklenen Mu'ammâ ve Lugazlar. Osmanlı Araştırmalart, 26, 205-222.

ELÇĩN, Ş. (2014). Halk Edebiyatına Giriş. 13. Baskı, Ankara: Akçağ Yayınları.

HAMZA, A. (2011). Türk Edebiyatında El Yazması Bir Lûgaz ve Mu'ammâ Mecmuasının Transkripsiyonlu Olarak Latin Harflerine Çevrilmesi. Yayımlanmamış Yüksek Lisans Tezi, Edirne: Trakya Üniversitesi Sosyal Bilimler Enstitüsü.

OLGUN, T. (1936). Edebiyat Lügati. İstanbul: Âsâr-1 İlmiye Kütüphanesi Neşriyatı.

PALA, İ. (2005). Ansiklopedik Divan Şiiri Sözlüğü. İstanbul: Kapı Yayınları.

SARAÇ, M. A. Y. (2007). Klasik Edebiyat Bilgisi Belagat. İstanbul: 3F Yayınevi. 


\section{Ekler}

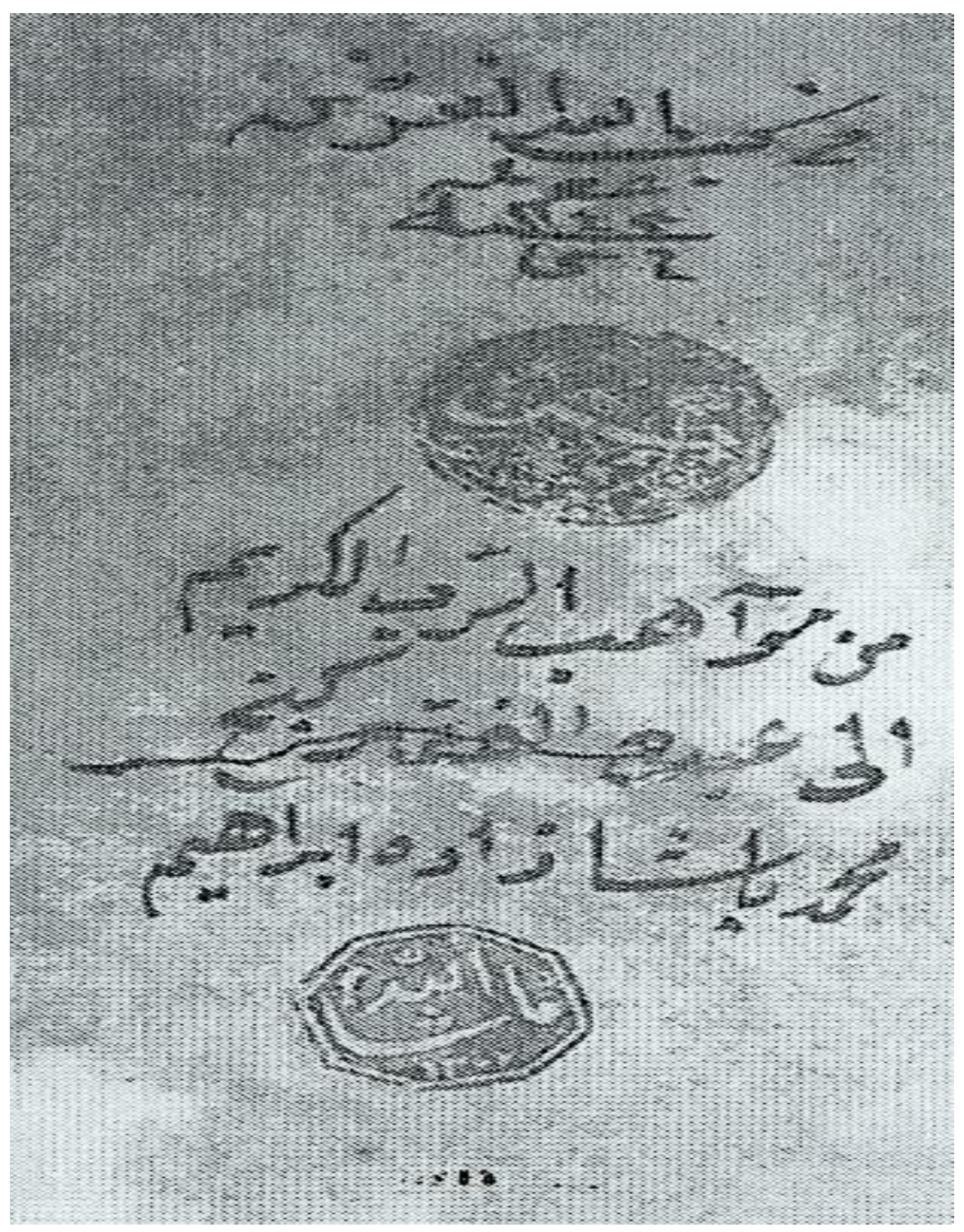

Metnin İç Kapăğ 


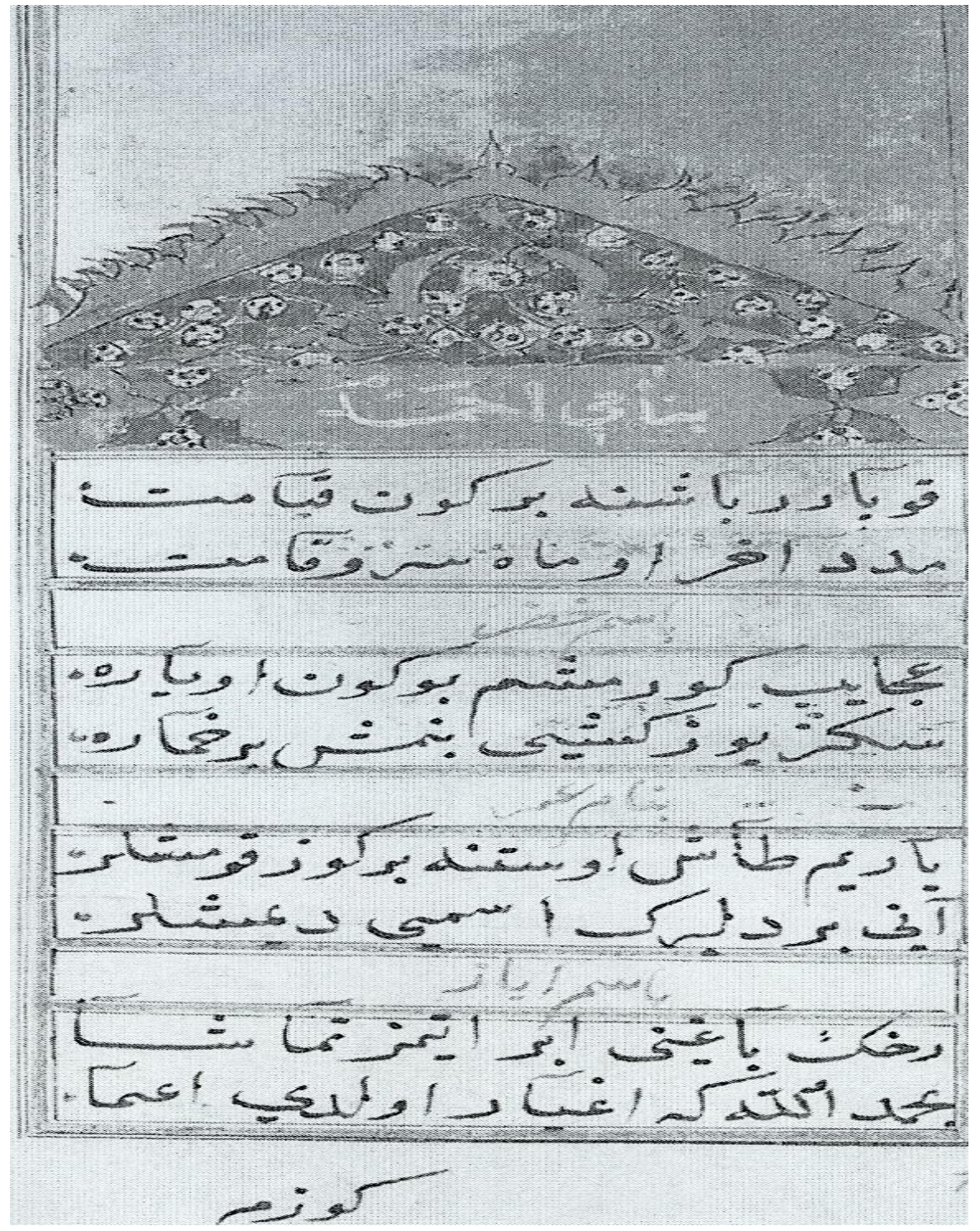

Metnin Illk Sayfası 


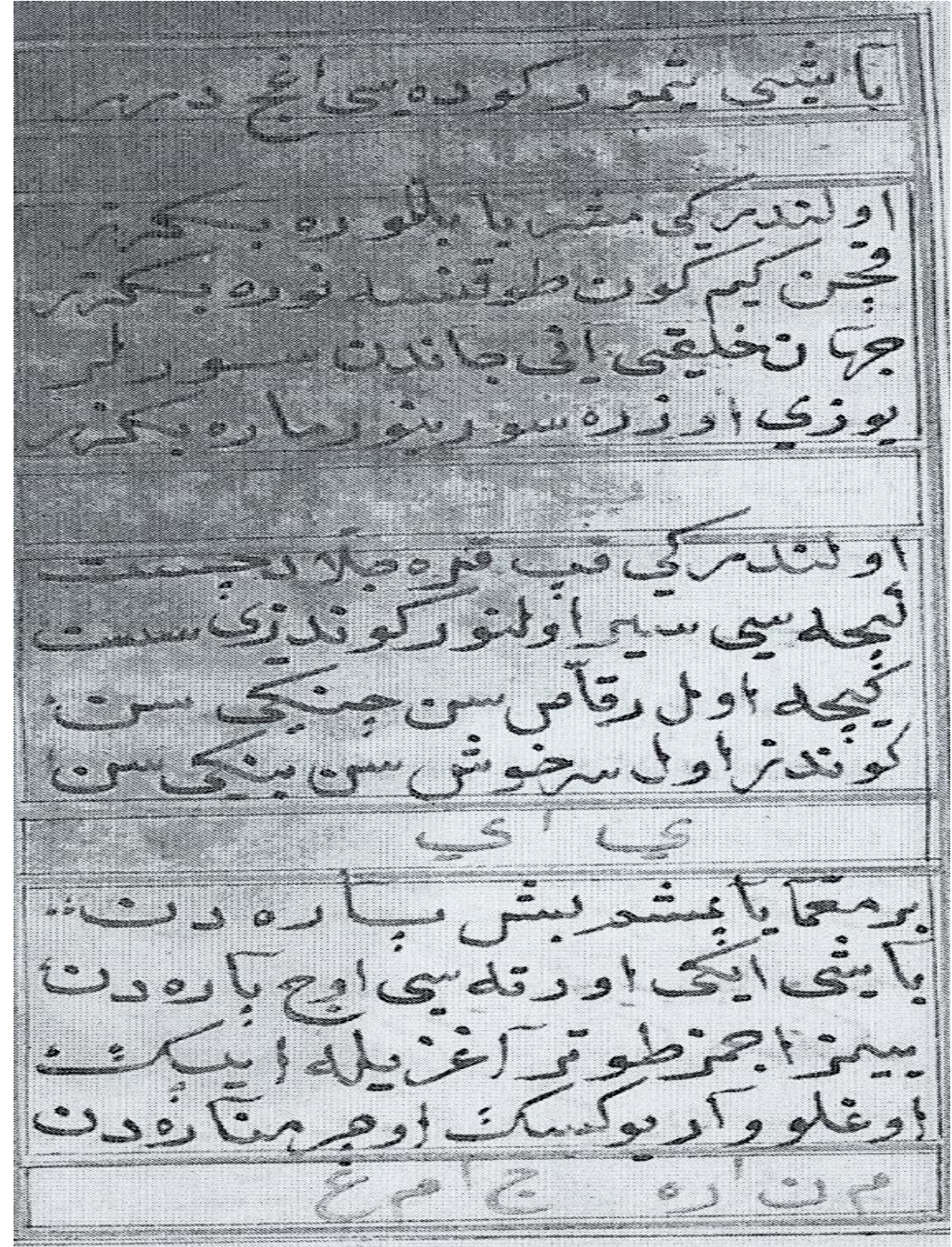

Silinmiş Başlık Satırlarından Bazıları 


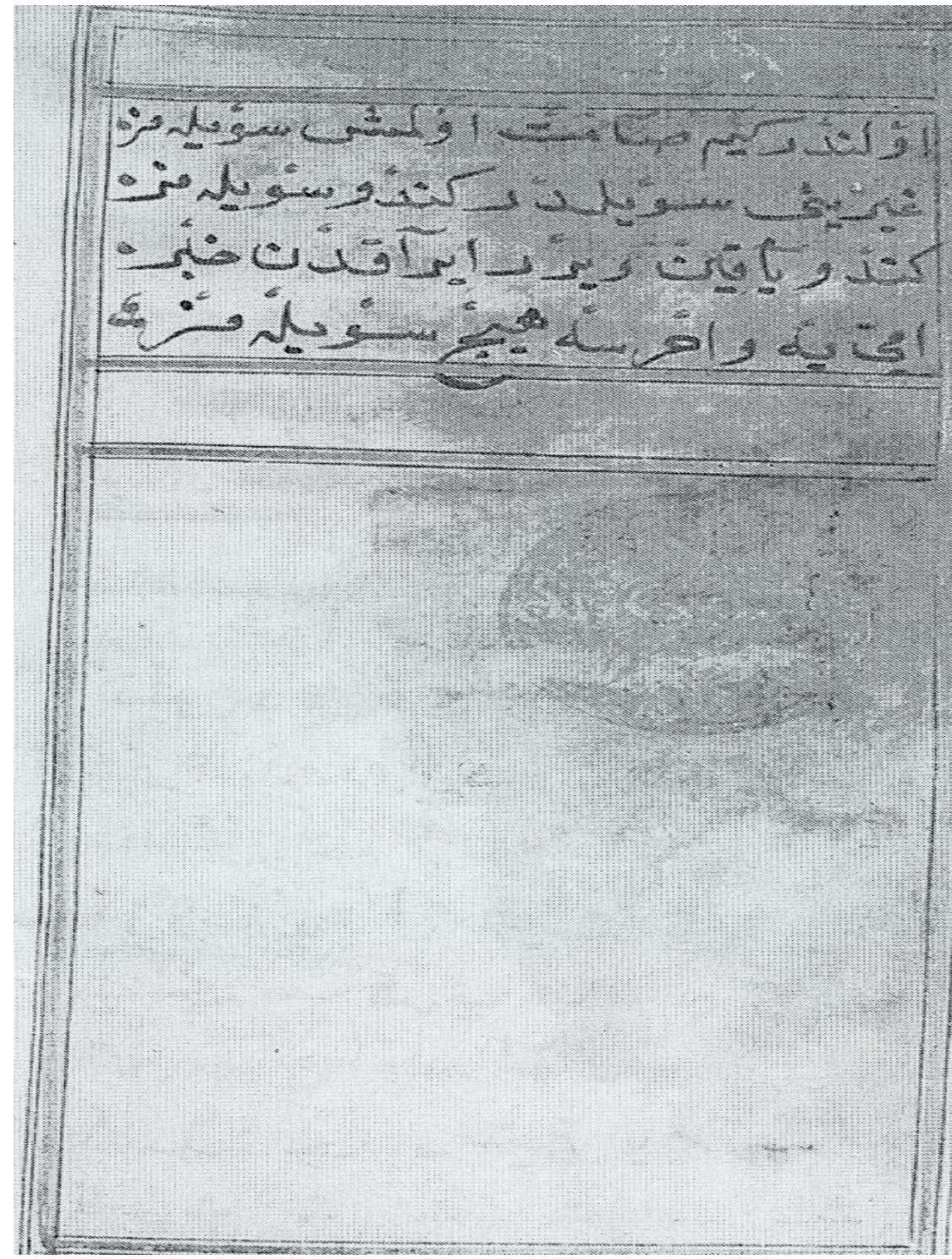

Metnin Son Sayfast 